\title{
THE CHILD WITH HAEMOPHILIA
}

\author{
C. D. KARABUS, M.B. Ch.B., M.Med. (Paed), D.C.H., M.R.C.P., F.R.C.P.E.*
}

\section{SUMMARY}

Haemophilias are bleeding disorders due to an inherited defect in production of clotting factors. In South Africa 867 haemophiliacs have been registered and 309 of these are boys under 15 years of age. Haemophilia $A$ and $B$ make up about $85-90 \%$ of all cases. They are inherited in a sex-linked manner and thus affect males only. The manifestations of haemophilia are due to blecdine charicteristically involving the joints. The disorder varies in severity and in the most severely affected children, repeated haemarthroses may lead to crippling. Early administration of clotting factor, preferably given at the child's home, physiotherapy to prevent muscle wasting and regular assessment by a co-ordinated team of paediatrician, physiotherapist, orthopaedic surgeon and dentist at the hospital are necessary $f r$ success/ul management. These facilities can be Irganised only at a comprehensive haemophilia treatment centre treating a large number of bleeders.

Haemophilia is a term used for a group of life-long bleeding disorders resulting from an inherited defect in the production of one or other of the plasma clotting factors. These proteins, responsible for normal blood coagulation, are designated by the Roman numerals I to XIII. The commonest disorder is haemophilia A or classic haemophilia which was probably recognised as early as the second century. The Babylonian Talmud describes a decision of Rabbi Simon ben Gamaliel to excuse from the rite of circumcision the newborn son of a woman whose sisters' sons bled to death on the basis that "there are families whose blood is loose, while in others it coagulates'. In 1803 the first modern description was given by $\mathrm{J}$. C. Otto. Haemophilia was called the 'bleeders disease' and later 'the disease of Kings' because of its occur-

* Haematology/Oncology Service, Red Cross War Memorial Children's Hospital and Department of Paediatrics, University of Cape Town.

Received 1 May 1981.

\section{OPSOMMING}

Hemofilie is 'n bloedingsiekte te wyle aan 'n oorgeerfle defek in die vervaardiging van stollingsfaktore. In Suid-Afrika is 867 hemofilielyers geregistreer en 309 gevalle is seuns onder 15 jaar. Hemofilie $A$ en $B$ beslaan omtrent $85-90 \%$ van alle gevalle. Hulle word oorgeërf in 'n seksgeskakelde manier en tas dus' slegs manlike lyers aan. Die kenmerke van hemofilie is te wyte aan bloedings, wat spesifiek gewrigte aantas. Die siekte varieer in die graad van aantasting en in die kinders wat ergste aangetas is, kan herhaalde hemartrose tot erge kreupelheid lei. Vroe è toediening van stollingsfaktor, verkiestik tuis, fisioterapie om spierverval te voorkom en gereëlde evaluering deur' $n$ gekoördineerde span bestaande uit 'n kinderspesialis, fisioterapeut, ortopediese chirurg en tandarts by die hospitaal is nodig vir sukss suolle hantering. Hierdie fasiliteite kan slegs bv 'n omvattende hemofilie behandelingsentrum, wat 'n groot aantal bloeiers behandel, georganiseer word.

rence among descendants of Queen Victoria in the royal families of Britain, Spain and Russia.

Haemophilia $A$ is due to a deficiency in factor VIII clotting activity while haemophilia B (Christmas Disease) results from defective factor IX production. Both are inherited in a recessive $X$-linked manner and therefore, with rare exceptions, are manifest only in males. Clinically haemophilia $\mathbf{A}$ and $\mathbf{B}$ are indistinguishable and together they make up about $85-90 \%$ of all cases of haemophilia. Haemophilia $A$ is 5 to 6 times more common than haemophilia B. Of the other haemophilias, Von Willebrand disease is the third most common, comprising about $10 \%$ of patients. All the other clotting factor deficiencies together make up less than $5 \%$ of cases. These disorders are autosomally transmitted and therefore may affect females as well as males.

\section{HAEMOPHILIA A AND B}

Haemophilia is relatively uncommon but not rare. The incidence of haemophilia $A$ and $B$ has been found 
to be between 10 and 15 per 100000 males in surveys done in the U.S.A. and various European countries. In South Africa (Karabus, 1981) 867 haemophiliacs have been identified and of the total 706 $(81 \%)$ have haemophilia $\mathrm{A}$ or $\mathrm{B}$ giving a prevalence of 5,4 per 100000 males. The figure for whites is the same as that in other countries while the incidence in blacks is much lower. There are 309 bovs under 15 known to have haemophilia $A$ or $B$ in the Republic and in this age group black bleeders outnumber whites.

\section{INHERITANCE AND NATUURE OF DEFECT}

The genes for haemophilia $A$ and $B$ are located at separate sites on the $X$ chromosome. Since there are no opposing genes on the $Y$ chromosome, the disorder is expressed only in the male (XY). Female (XX) carriers of the trait are generally unaffected, as they are able to produce sufficient clotting factor under the control of their normal $X$ chromosome. A haemophilic male cannot transmit the disorder to his sons but all his daughters must be carriers of haemophilia. A carrier female has a $50 \%$ risk of bearing a haemophilic son and her chance of having a carrier daughter is the same. In about one third of cases, there is no family history of the disorder and a spontaneous haemophilic mutation on the $X$ chromosome must have occurred. This defective gene can then be transmitted to subsequent generations.

For many years haemophilia was considered to be due to a quantitative deficiency of clotting factor. Fantl and co-workers (1956) discovered that haemophiliacs did produce a clotting factor molecule which did not function normally. Haemophilia is therefore due to a qualitative and not a quantitative abnormality of the clotting factor. The presence of a factor VIII protein which has reduced clotting activity has been a useful means of detecting female carriers of the disorder.

\section{MANIFESTATIONS}

All the problems in haemophilia result from excessive bleeding and its effect on the function of joints, muscles and other organs. The severity of the bleeding in haemophilia varies from case to case, in general being related to the amount of factor VIII or IX clotting activity present. This may range from 5 to $40 \%$. Severe bleeders have less than $2 \%$ clotting activity, moderately severe $2-5 \%$ and moderate to mildly affected individuals more than $5 \%$. The amount of factor present remains constant throughout the life of the haemophiliac. In haemophilia $A$ and $B$, all affected members of a familv have the same level of clotting activity and thus, usually, of severity of symptoms. Bleeding manifestations are most frequent and damaging during childhood. In severely affected cases, excessive bruising may be noticed during infancy as the baby starts crawling. Later as he learns to walk, haematomas on the forehead and face and bleeding from a cut lip or bitten tongue are not infrequent as a result of falls and bumps. The characteristic bleeding into joints usually becomes obvious from two to three years of age, commonly involving the ankles and knees. In the older child bleeds into the elbow joints are also frequent. Other joints such as the hips and shoulders are less often affected. The frequency of the bleeding episodes depends on the severity of the clotting defect and in children with less than $1 \%$ activity bleeds may occur weekly. The amount of trauma necessary to induce bleeding may be minimal in severe cases whereas mildly affected individuals may play sport such as tennis or soccer with little or no bleeding.
Bleeding into joints is the main cause of disability in haemophilia. Severe or repeated haemarthroses result eventually in the typical haemophylic arthropathy. The synovial tissues are thickened, a chronic effusion as a result of synovitis may be present and joint mobility is restricted. Muscle wasting around the joint is the rule, unless intensive physiotherapy is given. Weak muscles lead to instability of the joint and lack of protection against trauma which may cause further bleeding. Unless preventive measures are taken, this vicious cycle of bleeding, joint damage, muscle wasting, instability and further bleeding may repeat itself until the joint is totally destroyed. Eventually the joint may become almost immobile or chronic severe pain may necessitate arthrodesis or joint replacement. Radiologically, the joint space becomes narrowed, articular surfaces are irregular and defects in alignment may occur. In the knee there is often a valgus deformity of the leg which results in an abnormal strain being placed on the already damaged joint.

Bleeding may also involve muscles and result inf major loss of blood if the thigh, buttock or retroperitoneal muscles are involved. Nerves and blood vessels may be compressed if bleeding occurs into the calf, forearm or iliopsoas muscles and serious damage may follow unless intensive treatment is given. Bleeding into the renal tract is not uncommon in older children and may cause obstruction to urine flow. The most serious type of haemorrhage and the major cause of death in haemophilia is intracranial bleeding. This may be related to trauma to the head but in severe haemo. philiacs not infrequently there is no history of any precipitating cause. In view of this any haemophiliac who complains of a severe or prolonged headache should be given treatment for a potential cerebral haemorrhage.

\section{MANAGEMENT}

The overall management of the child with haemophilia is complicated and expensive. The cost of clotting factor alone needed to treat a single joint bleed in a boy of 10 may well amount to R250. In addition to the paediatrician or haematologist, the management team should also include a physiotherapist, orthopaedic surgeon, clinical nurse, social worker and dentist. Laboratory facilities should include technologists trained in coagulation and an adequate supply of treatmen materials. In view of the complexity of management and the relatively small number of haemophiliac patients, there is little doubt that centralisation is essential. In the USA, Britain and Europe large haemophilia centres have been established where the comprehensive care needed by the patient can be provided. It has been suggested (Levine, 1980) that a minimum number of 250 haemophiliacs are required in order to keep the services at a haemophilia centre functioning adequately.

\section{Treatment of Bleeding Episodes}

Fresh frozen plasma was first used as a means of replacing the missing clotting factor by Graham et al., in 1949. The effectiveness of these transfusions was limited by the large volume necessary to raise a patient's clotting factor sufficiently to stop bleeding. The plasma had to be stored deep frozen to retain its potency and this meant that children had to come to hospital for treatment. The usual hospital delays, including waiting for the plasma to thaw, inevitably led to the child missing school and falling behind in his education. More concentrated forms of factor VIII and IX are now available as cryoprecipitate or factor IX con- 
centrate and these can be dried for easy storage and reconstitution. Early treatment as soon as bleeding commences will reduce pain and disability. It should be emphasised that the patient and not the doctor is the best judge of whether a bleed has started.

Home treatment with administration of concentrate by the mother or even by the child himself should now be the rule for most severe bleeders. This reduces now be thent delay and decreases absence from school. The haemophiliac's life can be much more normal as he is no longer tied to a hospital; in addition expenses involved in hospital visits are spared. A close pelationship between the child on home treatment and the hospital, must, however, still be maintained. Patients should be able to telephone for advice about treatment and children should be seen at the haemophilia centre three to four times per year for a check by the team of paediatrician, physiotherapist, orthopaedic surgeon and dentist. Potentially dangerous bleeding such as suspected cerebral bleeding must always be treated at hospital.

The amount of factor replacement given depends on the severity of the bleed. For the average joint bleed about 10 units of factor VIII or 20 units of factor IX per kilogram body weight is given intravenously. This will raise the level of factor VIII or IX to $20 \%$ which is sufficient to stop bleeding. As the effect of infused clotting factor is only temporary, repeat doses may be necessary at 6-12 hour intervals until all pain disappears. Larger doses given for longer periods may be needed for more serious bleeding. The involved limb should be splinted to prevent movement and no weight bearing should be allowed until function is restored.

Physiotherapy is one of the most important aspects of treatment. The knee joint is most commonly involved in bleeding. Quadriceps wasting rapidly follows a haenarthrosis. To prevent this, static quadriceps exercises are started within hours of the bleed (as soon as movement is pain free) and this is followed by straight leg raising and extension exercises against graduated resistance. It is extremely important, and very difficult, to motivate small children to do physiotherapy at home. Parental co-operation must be obtained and repeated explanations of the importance of physiotherapy may be necessary.

Orthopaedic measures such as traction or serial wedging of plaster of paris splints to restore full exiension to a joint may be needed. Hofmann (1981) has emphasised the importance of maintaining normal joint alignment and advises supracondylar femoral osteotomy to correct the valgus deformity which often follows recurrent haemarthroses of the knee. He feels that physiotherapy is unlikely to be effective until alignment is corrected.

\section{Prophylactic Treatment}

Although most haemophilia centres advise treatment with factor concentrate for bleeding episodes only, Etzel (1980) has made a good case for treating severe haemophiliacs prophylactically. By regular twice weekly administration of factor concentrates the patient's clotting ability is maintained at a level at which he is unlikely to bleed frequently. Although the cost of such prophylactic treatment is high - in South African terms about R6 000 per year for a $25 \mathrm{~kg}$ boy - this must be offset against the possibly only slightly lower costs of acute treatment of recurrent bleeding episodes and the greater degree of crippling with its economic consequences which is likely to affect the acutely treated patient as compared to the haemophiliac receiving prophylactic therapy.

\section{Surgery}

Major surgery can be safely performed on the haemophilic patient and is best done at the haemophilia centres. Clotting factor inhibitors must be looked for and if present only absolutely essential and not elective surgery should be offered. Sufficient clotting factor should be infused just before operation to raise the patient's clotting above $60 \%$. This level must be maintained by $6-8$ hourly infusions until healing has occurred. The laboratory must be capable of doing frequent and: sometimes emergency clotting studies should problems arise.

\section{Clotting Factor Inhibitors}

In a few patients, mainly those with severe haemophilia A, factor VIII inhibitors or antibodies will develop. This is a serious complication as these antibodies inactivate any transfused clotting factor. Inhibitors usually appear in children or young adults and often in patients who have not been exposed to many transfusions.

It appears that certain haemophiliacs are susceptible to the development of inhibitors while others, though they may receive many more infusions, are non-susceptible (Strauss, 1969). Because of their failure to respond to infusion of factor concentrates, management of these patients is extremely difficult and, once again, should be undertaken only by an experienced haemophilia centre.

\section{Detection of Female Carriers and Genetic Counselling}

One of the major problems in haemophilia involves the mother who, with no family history of the disorder, has a haemophiliac son. Is she a carrier or is the affected son's haemophilia the result of a mutation? The same problem confronts the sister of a haemophiliac. Is she or is she not a carrier? The current method of detecting female carriers involves measuring the factor VIII clotting activity and the protein content (known as factor VIII related antigen). In normal individuals the ratio of factor VIII clotting activity to protein is one; in carriers it is generally less than 0,7. Bennett and Ratnoff (1973) have shown that about $90 \%$ of carrier women can be identified by this method. Once a girl is identified as a carrier, various options are available. If she wishes to have children, amniotic fluid can be sampled in order to sex the foetus and male foetuses can be aborted. In this way, however, she can only have daughters, who also have a $50 \%$ risk of being carriers, and there is also a $50 \%$ chance of aborting a completely normal foetus. Recently, the technique of foetal blood sampling has enabled antenatal diagnosis of haemophilia to be made. If termination of an affected foetus is acceptable, this will allow a mother to be certain of bearing a non-haemophiliac son.

Whatever option a carrier woman chooses, there is no question that with modern treatment, especially at a comprehensive treatment centre, the life of a haemophiliac boy today is vastly improved compared to his outlook in the past. Research is currently being directed towards the development of a synthetic oral treatment of the clotting deficiency. The exciting new field of genetic engineering, with its goal of replacing the haemophilia gene by a normal one, holds out hope at last of a cure for this ancient bleeding disorder.

\section{References}

Bennett, B. and Ratnoff, O. D. (1973). Detection of the carrier state for classic haemophilia. New Engl. J. Med., 288, 342 - 345 . 
Etzel, F. (1980). The cost of haemophilia treatment and the cost of lack of treatment. Presented at 1st International Haemophilia Conference, Bonn.

Fantl, P., Sawers, R. J. and Marr, A. G. (1956). Investigation of a haemorrhagic disease due to betaprothrombinase deficiency complicated by a specific inhibitor of thromboplastin formation. Australas. Ann. Med., 5, $163-176$.

Graham, J. B., Buckwalter, J. A., Hartley, L. J. and Brinkhous, K. M. (1949). Canine Hemophilia. Observations on the course, the clotting anomaly and the effect of blood tranfusion. J. Exp. Med, 90, $97-103$.
Hofmann, P., Schwuchow, E. P. and Roessler, R. (1980). Joint-conserving operations in haemophiliacs. Presented at 1 st International Haemophilia Conference, Bonn.

Karabus, C. D. (1981). Inherited bleeding disorders in South Africa: The SA Haemophilia Register. Submitted to SA Haemophilia Congress, Bloemfontein.

Levine, P. (1980). Comprehensive care programme for haemophiliacs. Presented at Ist International Haemophilia Conference, Bonn.

Strauss, H. S. (1969). Acquired circulating anticoagulants in Hemophilia A. New Engl. J. Med, 281, $866-873$ 